\section{JURNAL EKONOMI EFEKTIF}

ISSN : $2622-8882$, E-ISSN : 2622-9935

Jurnal Ekonomi Efektif, Vol. 3, No. 1, Oktober 2020 @Prodi Manajemen Fakultas Ekonomi Universitas Pamulang

\title{
PENGARUH KUALITAS PRODUK TERHADAP KEPUASAN KONSUMEN PADA KENTUCKY FRIED CHICKEN (KFC) BINTARO JAYA
}

\author{
Ahmad Nurhadi \\ Universitas Pamulang \\ dosen01023@unpam.ac.id
}

\begin{abstract}
ABSTRAK
Penelitian ini bertujuan untuk mengetahui pengaruh Kualitas Produk terhadap Kepuasan Konsumen pada Kentucky Fried Chicken (KFC) Bintaro Jaya. Metode yang digunakan adalah explanatory research dengan sampel sebanyak 82 responden. Teknik analisis menggunakan analisis statistik dengan pengujian regresi, korelasi, determinasi dan uji hipotesis. Hasil penelitian ini variabel Kualitas Produk diperoleh nilai rata-rata skor sebesar 3,41 dengan kriteria baik. Variabel Kepuasan Konsumen diperoleh nilai rata-rata skor sebesar 3,80 dengan kriteria baik. Kualitas Produk berpengaruh positif dan signifikan terhadap Kepuasan Konsumen dengan nilai persamaan regresi $Y=10,964+0,799 X$, dan nilai koefisien korelasi 0,762 atau memiliki tingkat hubungan yang kuat dengan nilai determinasi $58,1 \%$. Uji hipotesis diperoleh signifikansi $0,000<0,05$.
\end{abstract}

Kata Kunci: Kualitas Produk, Kepuasan Konsumen.

\begin{abstract}
This study aims to determine the effect of Product Quality on Consumer Satisfaction at Kentucky Fried Chicken (KFC) Bintaro Jaya. The method used is explanatory research with a sample of 82 respondents. The analysis technique uses statistical analysis with regression testing, correlation, determination and hypothesis testing. The results of this research variable Product Quality obtained an average score of 3.41 with good criteria. Consumer Satisfaction variable obtained an average score of 3.80 with good criteria. Product quality has a positive and significant effect on consumer satisfaction with the regression equation $Y=10.964+$ $0.799 X$, and the correlation coefficient value of 0.762 or has a strong level of relationship with a determination value of $58.1 \%$. Hypothesis testing obtained a significance of $0.000<0.05$.
\end{abstract}

Keywords: Product Quality, Customer Satisfaction. 


\section{PENDAHULUAN}

\section{A. Latar Belakang Masalah}

Pertumbuhan dan perkembangan perekonomian dewasa ini sangat sulit ditebak. Ini disebabkan oleh terjadinya perubahan di dunia baik di bidang ekonomi, sosial dan budaya. Hal ini juga tentunya akan mempengaruhi perkembangan struktur perekonomian secara global. Di samping itu dengan semakin berkembangnya perekonomian mengakibatkan timbulnya perusahaan-perusahaan baru, yang pada akhirnya meningkatkan persaingan antar perusahaan sehingga menjadi tantangan-tantangan bagi perusahaan untuk memenangkan persaingan dalam meningkatkan penjualan. Terlihat juga perusahaan-perusahaan yang memilih makanan siap saji yang masuk ke Indonesia.

Perubahan pada pola konsumsi masyarakat yang beranekaragam memunculkan konsep penghidangan makanan yang praktis, salah satunya adalah jenis fastfood (makanan cepat saji). Peluang usaha ini dimanfaatkan oleh banyak pemilik modal dalam industri restoran fastfood. Salah satu industri yang bergerak di bidang pengelola restoran siap saji adalah PT. Fast Food Indonesia, Tbk dengan merek dagang Kentucky Fried Chicken (KFC). Dalam menghadapi persaingan yang semakin ketat, banyak usaha yang dapat dilakukan oleh perusahaan. Namun salah satu yang dirasakan paling penting adalah memahami perilaku konsumen. Selain itu, pihak KFC harus mengetahui karakteristik konsumen secara umum. Hal ini dapat bermanfaat bagi perusahaan karena konsumsi produk setiap wilayah berbeda satu sama lain.

Berdasarkan hal tersebut maka permintaan terhadap makanan siap saji semakin meningkat, berarti merupakan peluang bisnis bagi pelaku bisnis makanan siap saji ini. Banyak sekali brand yang dipasarkan saat ini sehingga perusahaan harus cermat dalam menentukan strategi yang tepat.

Persaingan antar restoran cepat saji di Indonesia. Seharusnya menjadi keuntungan bagi KFC (Kentucky Fried Chicken) karena memiliki gerai cukup banyak hampir disetiap kecamatan atau wilayah bisnis. Selain itu, minat konsumen untuk mengunjungi sebuah restoran fastfood dapat mempengaruhi pertumbuhan gerai-gerai restoran cepat saji tersebut. Tingkat persaingan restoran fastfood dapat dipengaruhi oleh berbagai faktor seperti promosi, layanan, kenyamanan tempat, dan faktor lainnya. Selain itu banyaknya jumlah gerai turut mempengaruhi brand awareness konsumen terhadap merek/produk tersebut, sehingga tingkat persaingan semakin tinggi.

Restoran KFC pertama kali berdiri pada tahun 1930 di Sanders Court, Amerika oleh Harland Sanders. Tetapi mulai dikenal di Indonesia pada Oktober 1979 dengan dibukanya restoran KFC pertama di Jalan Melawai, Jakarta Selatan. KFC merupakan salah satu makanan siap saji yang menjadi top brand. Makanan siap saji ini diminati semua generasi baik muda maupun tua. KFC menyediakan makanan dan minuman yang cepat saji, yang dapat langsung dinikmati oleh para konsumennya. Restoran KFC ini mempunyai icon tersendiri yaitu "jagonya ayam", ini dikarenakan oleh menu utama yang ditawarkan oleh KFC adalah ayam goreng empuk dan renyah.

Disamping itu KFC juga menyediakan menu lainnya selain ayam goreng

seperti burger, twister, spaghetti, kentang, dan lainnya. Selain itu KFC juga menawarkan ragam menu 5000-an seperti sup, es krim, float, dan lain-lain. Kunci untuk mempertahankan kinerja bisnis adalah dengan memuaskan konsumen. Sebab, konsumen adalah kunci dari eksistensi perusahaan. Dengan memberikan kepada konsumen no reason to switch and every reason to stay berarti perusahaan telah mengisolasi (insulate) mereka dari tekanan kompetisi Jhonson \& Gustafsson (2000:113). Karena itu, tidak mengherankan bila kepuasan konsumen total customer satisfication. Menjadi tujuan utama (dominan goal) dari perusahaan-perusahaan yang inovatif. Artinya, tiga eksistensi 
kegiatan bisnis adalah memberikan pelayanan yang memuaskan kepada konsumen, sedangkan profitnya hanya merupakan konsekuensi logis yang akan muncul apabila konsumen puas.

Kepuasan konsumen merupakan respon konsumen terhadap ketidaksesuaian antara tingkat kepentingan sebelumnya dan kinerja aktual yang dirasakan setelah pemakaian Rangkuti (2002:73). Faktor dari kepuasan konsumen sendiri terdiri dari beberapa dimensi diantaranya : 1 . Kognitif yaitu kepercayaan seseorang mengenai apapun yang berlaku atau benar bagi objek sikap. 2. Afektif yaitu mengangkat masalah emosional objektif seseorang terhadap objek sikap. 3. Konatif yaitu menunjukan bagaimana prilaku atau kecenderungan berprilaku yang ada pada diri seseorang berkaitan dengan objek sikap.

Berdasarkan latar belakang tersebut, penulis tertarik untuk melakukan penelitian lebih mendalam dengan mengajukan judul skripsi "Analisa Pengaruh Kualitas Produk Terhadap Kepuasan Konsumen Pada Kentucky Fried Chicken (KFC) Bintaro Jaya”.

\section{B. Rumusan Masalah}

1. Bagaimana Kualitas Produk pada pada Kentucky Fried Chicken (KFC) Bintaro Jaya ?.

2. Bagaimana Kepuasan Konsumen pada Kentucky Fried Chicken (KFC) Bintaro Jaya ?.

3. Adakah pengaruh antara Kualitas Produk terhadap Kepuasan Konsumen pada Kentucky Fried Chicken (KFC) Bintaro Jaya?.

\section{Tujuan Penelitian}

1. Untuk mengetahui kondisi Kualitas Produk pada Kentucky Fried Chicken (KFC) Bintaro Jaya .

2. Untuk mengetahui kondisi Kepuasan Konsumen pada Kentucky Fried Chicken (KFC) Bintaro Jaya .

3. Untuk mengetahui pengaruh antara Kualitas Produk terhadap Kepuasan Konsumen pada Kentucky Fried Chicken (KFC) Bintaro Jaya.

\section{METODE PENELITIAN}

\section{Populasi}

Populasi dalam penelitian ini berjumlah 82 responden yaitu konsumen Kentucky Fried Chicken (KFC) Bintaro Jaya

\section{Sampel}

Teknik pengambilan sampling dalam penelitian ini adalah samplel jenuh, dimana semua anggota populasi dijadikan sebagai sampel. Dengan demikian sampel dalam penelitian ini berjumlah 82 responden.

\section{Jenis Penelitian}

Jenis penelitian yang dipakai adalah asosiatif, dimana tujuannya adalah untuk mengetahui mencari keterhubungan antara variabel independen terhadap variabel dependennya

\section{Metode Analisis Data}

Dalam menganalisis data digunakan uji validitas, uji reliabilitas, analisis regresi linier sederhana, koefisien korelasi, koefisien determinasi dan uji hipotesis. 


\section{HASIL PENELITIAN DAN PEMBAHASAN}

\section{Analisis Deskriptif}

Pada pengujian ini digunakan untuk mengetahui skor minimum dan maksimum skor tertinggi, ratting score dan standar deviasi dari masing-masing variabel. Adapun hasilnya sebagai berikut:

Tabel 1. Hasil Analisis Descriptive Statistics

\section{Descriptive Statistics}

\begin{tabular}{lr|r|r|r|r} 
& N & Minimum & Maximum & Mean & \multicolumn{1}{c}{ Std. Deviation } \\
\hline Kualitas Produk (X1) & 82 & 28 & 44 & 34.10 & 4.014 \\
\hline Kepuasan Konsumen (Y) & 82 & 29 & 49 & 38.04 & 4.206 \\
\hline Valid N (listwise) & 82 & & & & \\
\hline
\end{tabular}

Kualitas Produk diperoleh varians minimum sebesar 28 dan varians maximum 44 dengan ratting score sebesar 3,41 dengan standar deviasi 4,014. Skor ini termasuk pada rentang sakala 3,40 - 4,19 dengan kriteria baik atau setuju.

Kepuasan Konsumen diperoleh varians minimum sebesar 29 dan varians maximum 49 dengan ratting score sebesar 3,80 dengan standar deviasi 4,206. Skor ini termasuk pada rentang sakala 3,40 - 4,19 dengan kriteria baik atau setuju.

\section{Analisis Verifikatif.}

Pada analisis ini dimaksudkan untuk mengetahui pengaruh variabel independen terhadap variabel dependen. Adapun hasil pengujian sebagai berikut:

\section{a. Analisis Regresi Linier Sederhana}

Uji regresi ini dimaksudkan untuk mengetahui perubahan variabel dependen jika variabel independen mengalami perubahan. Adapun hasil pengujiannya sebagai berikut:

Tabel 2. Hasil Pengujian Regresi Linier Sederhana Coefficients $^{\mathrm{a}}$

\begin{tabular}{|c|c|c|c|c|c|}
\hline \multirow[b]{3}{*}{ Model } & \multicolumn{2}{|c|}{ Coetticlents $^{\circ}$} & \multirow{2}{*}{$\begin{array}{l}\text { Standardized } \\
\text { Coefficients }\end{array}$} & \multirow[b]{3}{*}{$\mathrm{t}$} & \multirow[b]{3}{*}{ Sig. } \\
\hline & $\begin{array}{r}\text { Unsta } \\
\text { Coe }\end{array}$ & $\begin{array}{l}\text { dardized } \\
\text { ficients }\end{array}$ & & & \\
\hline & B & Std. Error & Beta & & \\
\hline 1 (Constant) & 10.964 & 2.589 & & 4.235 & .000 \\
\hline Kualitas Produk $(X)$ & .799 & .076 & .762 & 10.530 & .000 \\
\hline
\end{tabular}

Berdasarkan hasil pengujian pada tabel di atas, diperoleh persamaan regresi $\mathrm{Y}$ $=10,964+0,799 X$. Dari persamaan tersebut dijelaskan sebagai berikut:

1) Konstanta sebesar 10,964 diartikan jika Kualitas Produk tidak ada, maka telah terdapat nilai Kepuasan Konsumen sebesar 10,964 point.

2) Koefisien regresi Kualitas Produk sebesar 0,799, angka ini positif artinya setiap ada peningkatan Kualitas Produk sebesar 0,799 point maka Kepuasan Konsumen juga akan mengalami peningkatan sebesar 0,799 point.

\section{b. Analisis Koefisien Korelasi}

Analisis koefisien korelasi dimaksudkan untuk mengetahui tingkt kekuatan hubungan dari variabel independen terhadap variabel dependen baik secara parsial maupun simultan. Adapun hasil pengujian sebagai berikut: 
Tabel 3. Hasil Pengujian Koefisien Korelasi Kualitas Produk Terhadap Kepuasan Konsumen. Correlations $^{b}$

\begin{tabular}{llr|r} 
& & $\begin{array}{c}\text { Kualitas } \\
\text { Produk (X1) }\end{array}$ & $\begin{array}{c}\text { Kepuasan } \\
\text { Konsumen }(\mathrm{Y})\end{array}$ \\
\hline Kualitas Produk (X1) & Pearson Correlation & 1 & $.762^{* *}$ \\
\cline { 2 - 4 } & Sig. (2-tailed) & & .000 \\
\hline Kepuasan Konsumen (Y) & Pearson Correlation & $.762^{* *}$ & 1 \\
\cline { 2 - 4 } & Sig. (2-tailed) & .000 &
\end{tabular}

Berdasarkan hasil pengujian diperoleh nilai korelasi sebesar 0,762 artinya Kualitas Produk memiliki hubungan yang kuat terhadap Kepuasan Konsumen.

c. Analisis Koefisien Determinasi

Analisis koefisien determinasi dimaksudkan untuk mengetahui besarnya persentase pengaruh dari variabel independen terhadap variabel dependen. Adapun hasil pengujian sebagai berikut:

Tabel 4. Hasil Pengujian Koefisien Determinasi Kualitas Produk Terhadap Kepuasan Konsumen. Model Summary

\begin{tabular}{|c|c|c|c|c|}
\hline \multicolumn{5}{|c|}{ Nover suitiliary } \\
\hline Model & $\mathrm{R}$ & R Square & $\begin{array}{l}\text { Adjusted R } \\
\text { Square }\end{array}$ & $\begin{array}{l}\text { Std. Error of the } \\
\text { Estimate }\end{array}$ \\
\hline 1 & $.762^{\mathrm{a}}$ & .581 & .576 & 2.740 \\
\hline
\end{tabular}

Berdasarkan hasil pengujian diperoleh nilai determinasi sebesar 0,581 artinya Kualitas Produk memiliki kontribusi pengaruh sebesar 58,1\% terhadap Kepuasan Konsumen.

\section{d. Uji Hipotesis}

Pengujian hipotesis dengan uji t digunakan untuk mengetahui hipotesis mana yang diterima.

Rumusan hipotesis: Terdapat pengaruh yang signifikan antara Kualitas Produk terhadap Kepuasan Konsumen.

Tabel 5. Hasil Uji Hipotesis Kualitas Produk Terhadap Kepuasan Konsumen.

\begin{tabular}{|c|c|c|c|c|c|}
\hline \multirow[b]{2}{*}{ Model } & \multicolumn{2}{|c|}{$\begin{array}{l}\text { Coefficients }^{\mathbf{a}} \\
\text { Unstandardized } \\
\text { Coefficients }\end{array}$} & \multirow[t]{2}{*}{$\begin{array}{c}\text { Standardized } \\
\text { Coefficients } \\
\text { Beta }\end{array}$} & \multirow[b]{2}{*}{$\mathrm{t}$} & \multirow[b]{2}{*}{ Sig. } \\
\hline & B & Std. Error & & & \\
\hline 1 (Constant) & 10.964 & 2.589 & & 4.235 & .000 \\
\hline Kualitas Produk (X) & .799 & .076 & .762 & 10.530 & .000 \\
\hline
\end{tabular}

Berdasarkan hasil pengujian pada tabel di atas, diperoleh nilai $t$ hitung $>\mathrm{t}$ tabel atau $(10,530>1,990)$, dengan demikian hipotesis yang diajukan bahwa terdapat pengaruh yang signifikan atara Kualitas Produk terhadap Kepuasan Konsumen diterima.

\section{PEMBAHASAN HASIL PENELITIAN}

\section{Kondisi Jawaban Responden Variabel Kualitas Produk}

Berdasarkan jawaban responden, variabel Kualitas Produk diperoleh ratting score sebesar 3,41 berada di rentang skala 3,40 - 4,19 dengan kriteria baik atau setuju.

2. Kondisi Jawaban Responden Variabel Kepuasan Konsumen

Berdasarkan jawaban responden, variabel Kepuasan Konsumen diperoleh ratting score sebesar 3,80 berada di rentang skala 3,40 - 4,19 dengan kriteria baik atau setuju. 


\section{Pengaruh Kualitas Produk Terhadap Kepuasan Konsumen}

Kualitas Produk berpengaruh signifikan terhadap Kepuasan Konsumen dengan persamaan regresi $\mathrm{Y}=10,964+0,799 \mathrm{X}$, nilai korelasi sebesar 0,762 atau memiliki hubungan yang kuat dengan kontribusi pengaruh sebesar 58,1\%. Pengujian hipotesis diperoleh nilai $t$ hitung $>t$ tabel atau $(10,530>1,990)$. Dengan demikian hipotesis yang diajukan bahwa terdapat berpengaruh signifikan antara Kualitas Produk terhadap Kepuasan Konsumen diterima.

\section{PENUTUP}

\section{Kesimpulan}

a. Variabel Kualitas Produk diperoleh ratting score sebesar 3,41 berada di rentang skala 3,40 - 4,19 dengan kriteria baik atau setuju.

b. Variabel Kepuasan Konsumen diperoleh ratting score sebesar 3,80 berada di rentang skala 3,40 - 4,19 dengan kriteria baik atau setuju.

c. Kualitas Produk berpengaruh signifikan terhadap Kepuasan Konsumen dengan persamaan regresi $\mathrm{Y}=10,964+0,799 \mathrm{X}$, nilai korelasi sebesar 0,762 atau kuat dan kontribusi pengaruh sebesar 58,1\% sedangkan sisanya sebesar 57,9\% dipengaruhi faktor lain. Uji hipotesis diperoleh nilai t hitung $>\mathrm{t}$ tabel atau $(10,530>1,990)$.

\section{Saran}

a. Diharapkan kualitas produk yang sudah baik terus dipertahankan dan ditingkatkan supaya konsumen bisa merasa puas. Perusahaan lebih menerima masukan dari konsumen sebagai bahan pertimbangan untuk mengembangkan lagi produknya sehingga pilihan yang tersedia pun semakin banyak dan beragam.

b. Perlu diadakan survei pasar secara periodik, baik terhadap pelanggan maupun perusahaan pesaing. Pada akhirnya perusahaan selalu mengetahui apa yang di butuhkan (Needs), diinginkan (Wants) dan di harapkan (Expectations) oleh pelanggan, sehingga mampu menciptakan suatu kepuasan bagi pelanggan.

c. Penelitian ini dapat dilanjutkan oleh penelitian lain dengan menggunakan variable independen yang lain.

\section{DAFTAR PUSTAKA}

Algifari. (2015). "Analisis Regresi untuk Bisnis dan Ekonomi”. Yogyakarta: BPFE.

Arikunto, Suharsimi (2014). "Prosedur Penelitian Suatu Pendekatan Praktek”. Jakarta: Rineka Cipta.

Bashu Swastha dan T. Handoko (2015) Manajemen Pemasaran Moderen, Yogyakarta: BPFE.

Basu Swastha Dharmmesta. (2014). Manajemen Pemasaran. BPFE: Yogyakarta. Buchari Alma. 2014. Manajemen pemasaran dan Pemasaran Jasa. Edisi Revisi.

Bilson Simamora (2016) Panduan Riset Prilaku Konsumen, Jakarta: PT. Gramedia Pustaka.

Fandy Tjiptono (2017), Serivce Quality and Satisfiation. Jakarta: Edisi tiga. Andi.

Freddy Rangkuti (2016) Strategi Promosi Yang Kreatif, Edisi Pertama, Cetakan Pertama Jakarta: Gramedia Pustaka Utama.

Imam Ghozali (2017). "Aplikasi Analisis Multivariate Dengan Program SPSS”. Edisi Kelima. Semarang: Badan Penerbit Undip.

Istijanto (2014) “Riset Sumber Daya Manusia”. Jakarta: PT. Gramedia Pustaka

Kharis, Ismu Fadli (2011). "Studi Mengenai Impulse Buying dalam Penjualan Online”. Semarang : Skripsi Universitas Diponegoro 
Kotler dan Amstrong (2017), Prinsip-prinsip Pemasaran. Edisi Kedua Belas”. Jilid Satu. Jakarta: Erlangga.

Lupiyoadi (2016) Manajemen Pemasaran Jasa, Edisi 4, Jakarta: Salemba Empat.

Philip Kotler (2017) Manajemen Pemasaran, Edisi Keempat Belas, Jakarta: PT. Indeks.

Phipil Kotler dan Kevin Keller (2017) Manajemen Pemasaran, Edisi Kedua Belas, Jilid Satu, Jakarta: Erlangga.

Rao, Purba, (2012). "Measuring Consumer Perceptions Through Factor Analysis", The Asian.

Santoso, Singgih (2015). “Menguasai Statistik Multivariat”. Jakarta: PT Elex Media Komputindo.

Sudjana (2014) “Metode Statistika”, Bandung: Tarsido.

Sugiyono (2017), "Metode Penelitian Administrasi : dilengkapi dengan Metode $R \&$ D”. Bandung: Alfabeta.

Suhartanto (2014). “Metode Riset Pemasaran”. Bandung: Alfabeta

Sunarsi, D. (2016, October). Pengaruh Minat, Motivasi Dan Kecerdasan Kognitif Terhadap Prestasi Belajar (Studi Kasus Pada Mahasiswa Program Studi S-1 Manajemen. Fakultas Ekonomi. Universitas Pamulang. Thn. Akademik 2015-2016). In Proceedings (Vol. 1, No. 1).

Sunarsi, D. (2017). Pengaruh Rekrutmen, Seleksi dan Pelatihan Terhadap Produktivitas Kerja Karyawan PT Mercolade Tangerang.

Sunarsi, D. (2018). Pengembangan Sumber Daya Manusia Strategik \& Karakterisrik Sistem Pendukungnya : Sebuah Tinjauan. Jurnal Ilmiah MEA (Manajemen, Ekonomi, \& Akuntansi). Vol 2 No 3. 